\title{
Polarizing a Hydrophobic Cavity for the Efficient Binding of Organic Guests: the Case of Calix[6]tren, a Highly Efficient and Versatile Receptor for Neutral or Cationic Species
}

Ulrich Darbost, ${ }^{\dagger}$ Marie-Noëlle Rager, ${ }^{\ddagger}$ Samuel Petit, ${ }^{\S}{\text { Ivan } \text { Jabin }^{\dagger *} \text { and Olivia Reinaud }}^{\ddagger *}$

\section{Supporting Information}

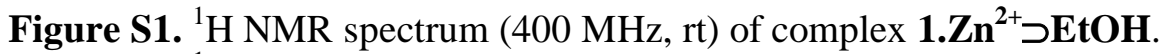

Figure S2. ${ }^{1} \mathrm{H}$ NMR spectra $\left(300 \mathrm{MHz}, \mathrm{CDCl}_{3}\right)$ of $\mathbf{1 . \mathbf { H } ^ { + }}$ at $293 \mathrm{~K}$ and $233 \mathrm{~K}$.

Figure S3. ${ }^{1} \mathrm{H}$ NMR spectra $\left(300 \mathrm{MHz}, \mathrm{CDCl}_{3}\right.$ ) of the mixture of cryptand $\mathbf{1 . \mathbf { H } ^ { + }}$ and $\mathbf{1} \supset \mathbf{P r N H}{ }_{3}{ }^{+}$at $293 \mathrm{~K}$ and $233 \mathrm{~K}$.

Figure S4. ${ }^{1} \mathrm{H}$ NMR spectrum (400 MHz, $\left.243 \mathrm{~K}\right)$ of complex $1 . \mathbf{Z n}^{2+} \supset \mathbf{P r N H}_{2}$.

Figure S5. ${ }^{1} \mathrm{H}$ NMR spectrum $\left(300 \mathrm{MHz}, \mathrm{CDCl}_{3}\right)$ recorded at $223 \mathrm{~K}$ of tetra-cationic cryptand $1.4 \mathbf{H}^{+}$.

Figure S6. ${ }^{13} \mathrm{C}$ spectrum $(75 \mathrm{MHz})$ recorded at $\mathrm{rt}$ in $\mathrm{CDCl}_{3}$, of $\mathbf{1 . 4 \mathbf { H } ^ { + }}$.

Figure S7. COSY spectrum, recorded at $\mathrm{rt}$ in $\mathrm{CDCl}_{3}$, of $\mathbf{1 . 4 \mathbf { H } ^ { + }}$.

Figure S8. HMQC spectrum, recorded at $\mathrm{rt}$ in $\mathrm{CDCl}_{3}$, of $\mathbf{1 . 4 \mathbf { H } ^ { + }}$.

Figure S9. Van't Hoff plot of the equilibrium constant $\mathrm{K}_{\mathrm{DMF} / \mathrm{H} 2 \mathrm{O}}$ determined by ${ }^{1} \mathrm{H} \mathrm{NMR}$ in $\mathrm{CDCl}_{3}$ solution.

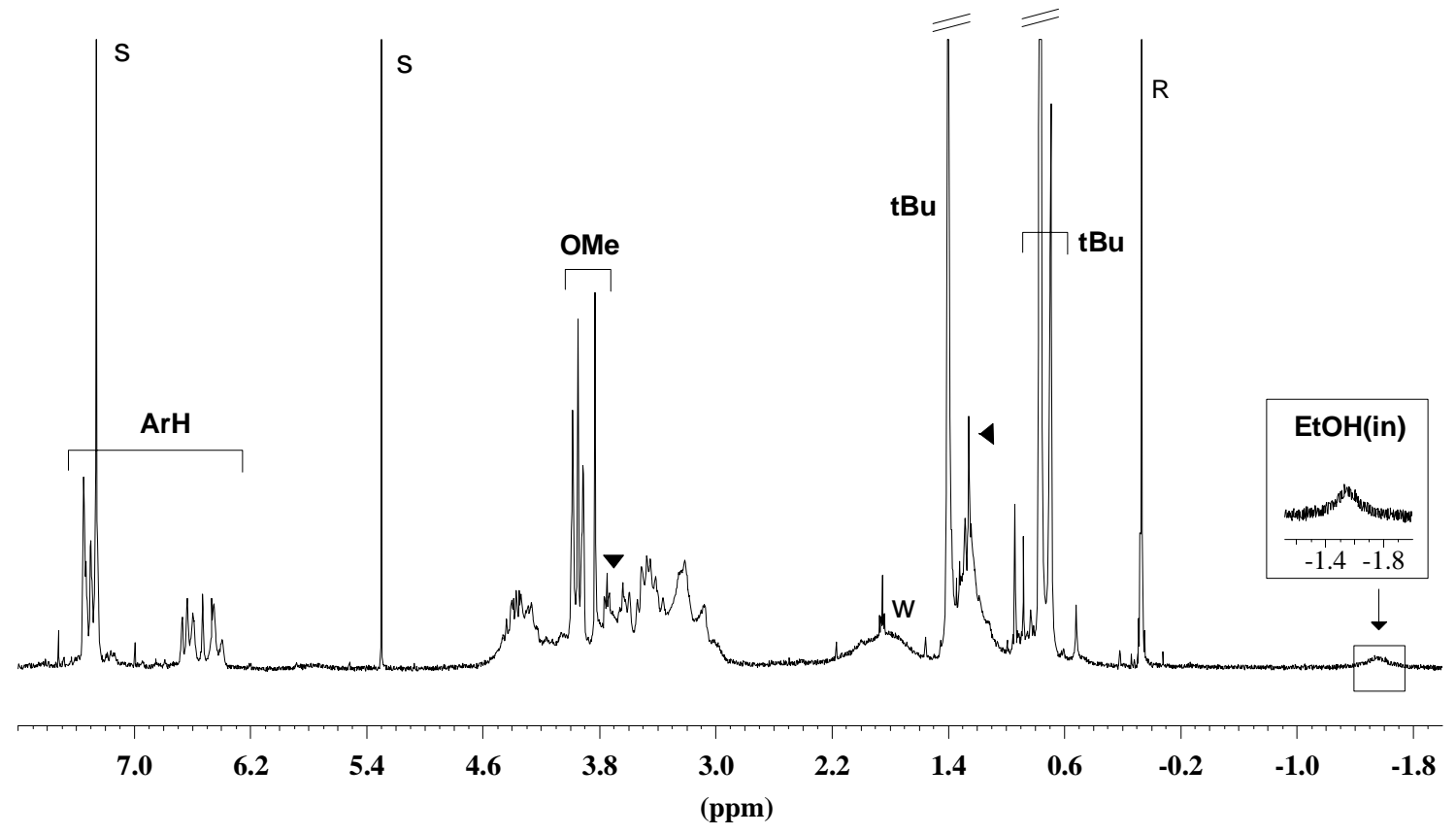

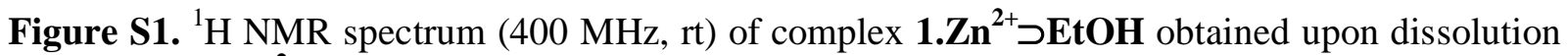
of complex $1 . \mathbf{Z n}^{2+}$ in $\mathrm{CDCl}_{3}$ in presence of an excess of EtOH. $\mathbf{v}$ : free EtOH. Residual solvents, water and reference have been labeled "S", "W" and "R", respectively. 


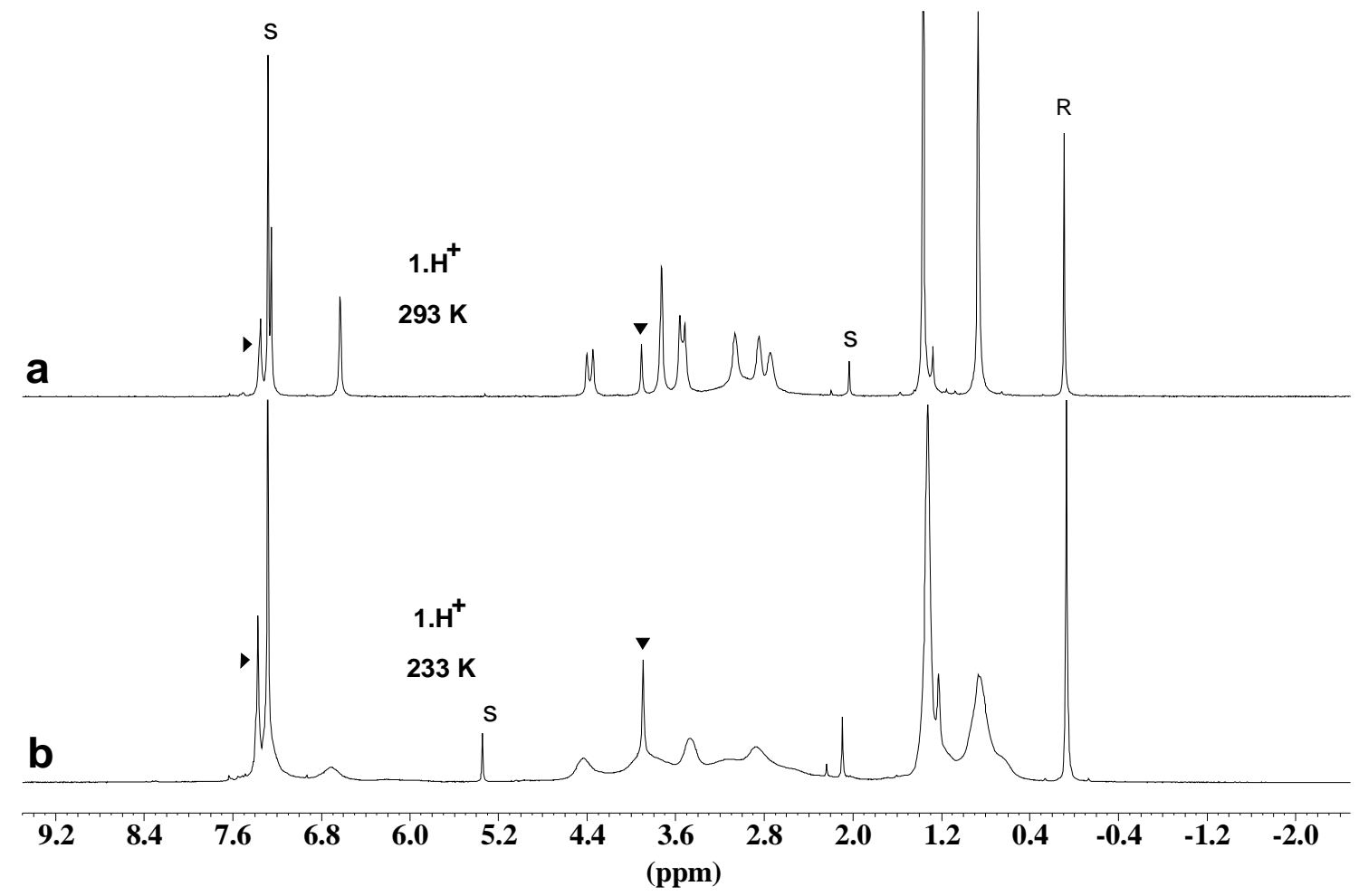

Figure S2. ${ }^{1} \mathrm{H}$ NMR spectra $\left(300 \mathrm{MHz}, \mathrm{CDCl}_{3}\right)$ of $\mathbf{1 . H ^ { + }}$. a: at $293 \mathrm{~K}$; b: at $233 \mathrm{~K}$. $\mathbf{v}$ : signals of free $\mathrm{BnNH}_{2}$. 


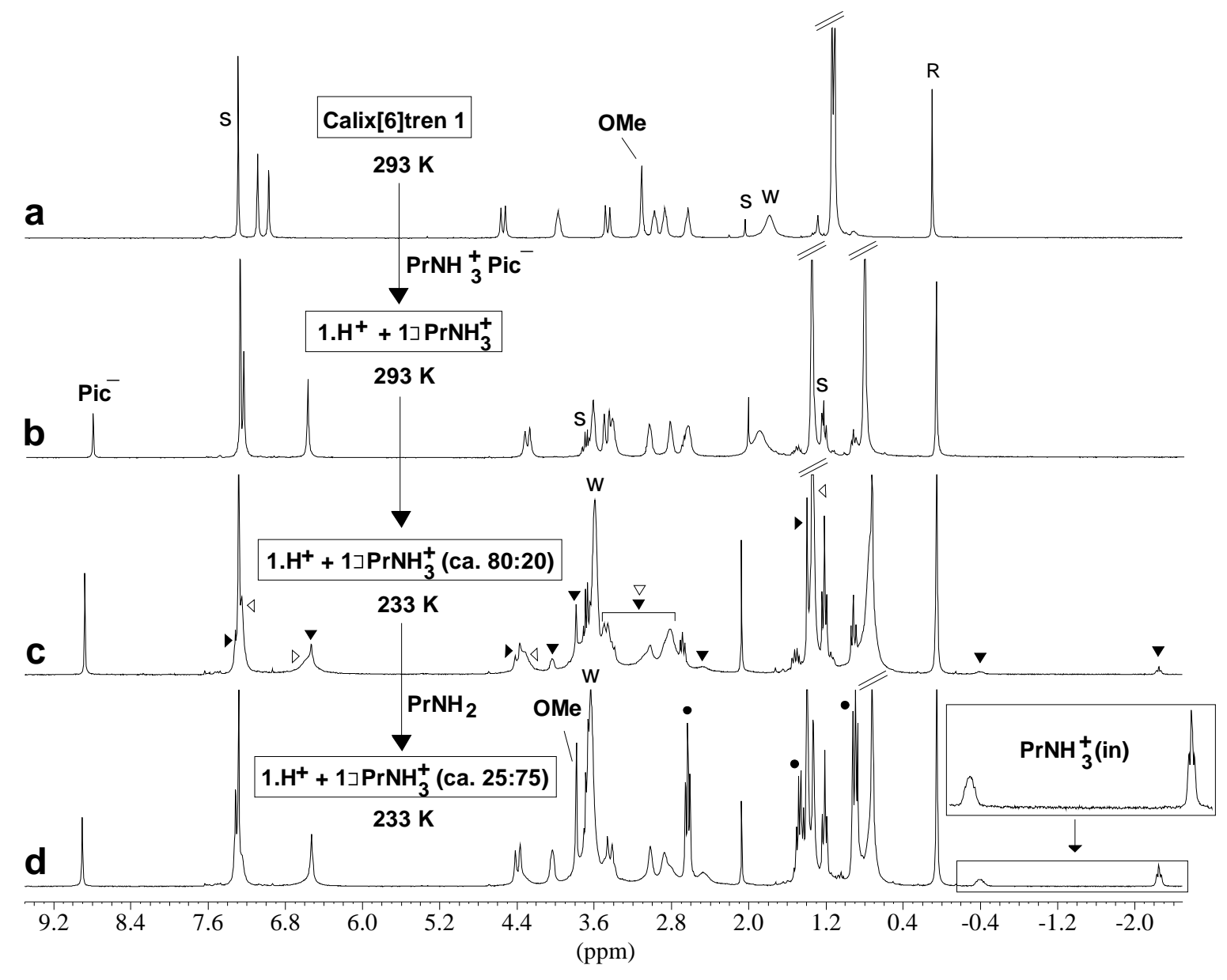

Figure S3. ${ }^{1} \mathrm{H}$ NMR spectra $\left(300 \mathrm{MHz}, \mathrm{CDCl}_{3}\right)$. a: Calix[6]tren 1, $293 \mathrm{~K}$. b: mixture of $\mathbf{1} \supset \mathbf{P r N H}_{\mathbf{3}}{ }^{+}$ and $\mathbf{1 .} \mathbf{H}^{+}(293 \mathrm{~K})$ obtained upon addition of picrate salt $\mathrm{PrNH}_{3}{ }^{+} \mathrm{Pic}^{-}$(1 equiv.) into a $\mathrm{CDCl}_{3}$ solution of 1. c: ca. 80:20 mixture of $\mathbf{1} \supset \mathbf{P r N H}_{3}{ }^{+}$and $\mathbf{1 . H ^ { + }}, 233 \mathrm{~K}$. d: $c a .25: 75$ mixture of $\mathbf{1} \supset \mathbf{P r N H}{ }_{3}{ }^{+}$and 1. $\mathbf{H}^{+}(233 \mathrm{~K})$ obtained by subsequent addition of excess $\mathrm{PrNH}_{2}$ (ca. 5 equiv.). $\mathbf{\nabla}$ : signals of $\mathbf{1}_{\supset} \mathbf{P r N H}_{3}{ }^{+}$; $\sigma$ : signals of $\mathbf{1 . H ^ { + }}$; •: signals of free $\mathrm{PrNH}_{2}$. Residual solvents, partially protonated water and reference have been labeled "S", "W" and "R"respectively. 


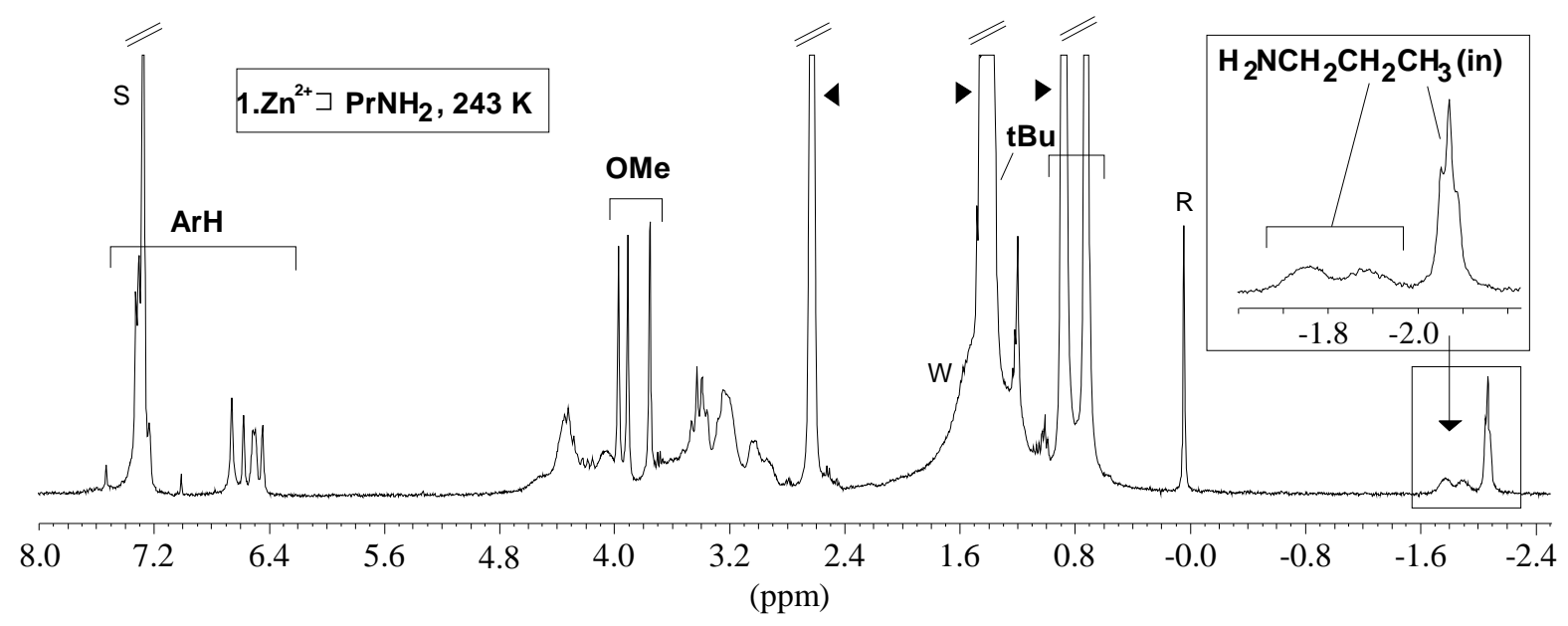

Figure S4. ${ }^{1} \mathrm{H}$ NMR spectrum $(400 \mathrm{MHz}, 243 \mathrm{~K})$ of complex $\mathbf{1 . Z n ^ { 2 + }} \supset \mathbf{P r N H}_{\mathbf{2}}$ obtained after dissolution of complex $1 . \mathrm{Zn}^{2+}$ in $\mathrm{CDCl}_{3}$ in presence of an excess of $\mathrm{PrNH}_{2}$. $\mathbf{\nabla}$ : free $\mathrm{PrNH}_{2}$. Residual solvents, water and reference have been labeled "S", "W" and "R", respectively. 


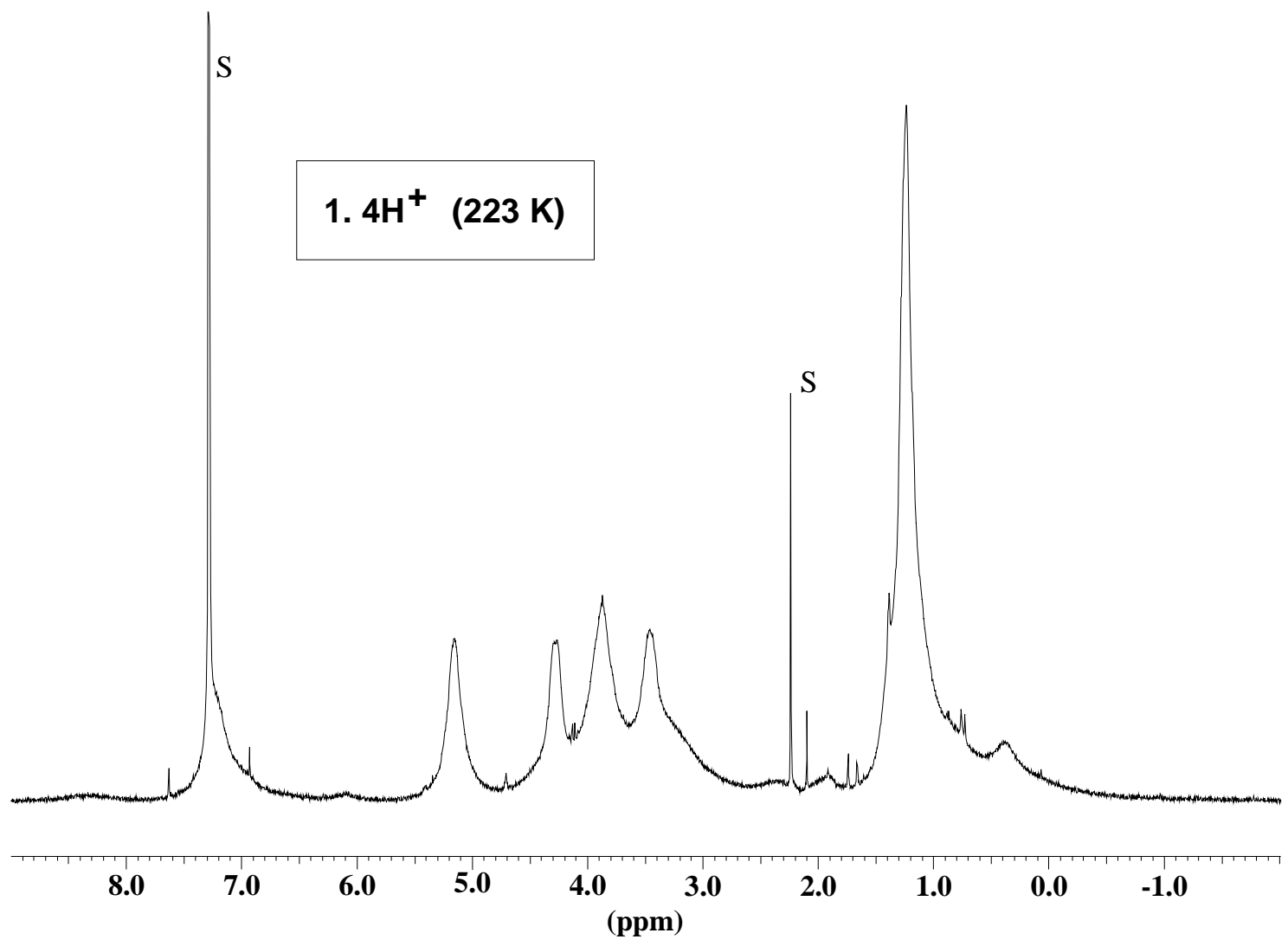

Figure S5. ${ }^{1} \mathrm{H}$ NMR spectrum $\left(300 \mathrm{MHz}, \mathrm{CDCl}_{3}\right)$ recorded at $223 \mathrm{~K}$ of tetra-cationic cryptand $\mathbf{1 . 4 H}$. Residual solvents have been labeled "S". 


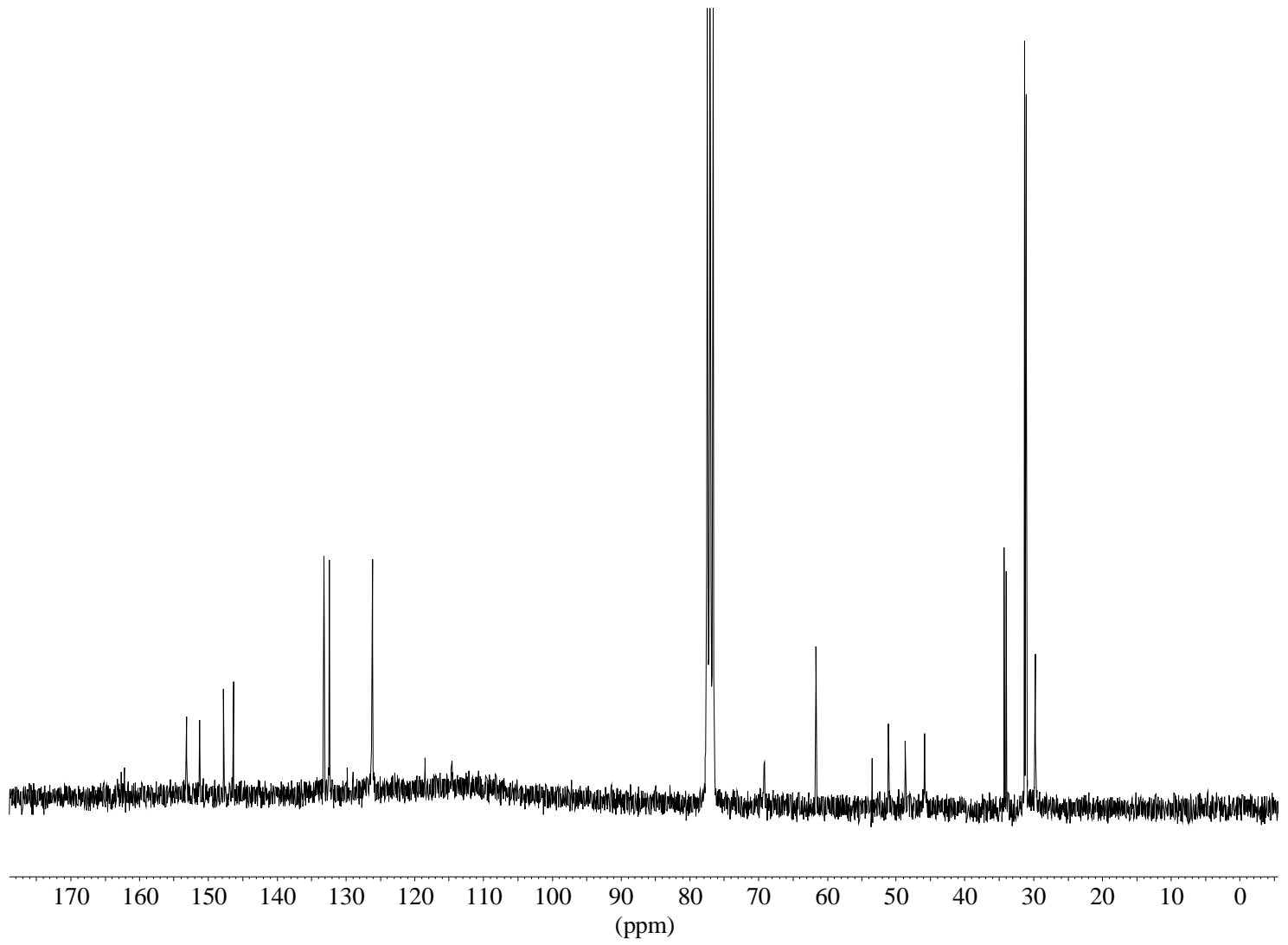

Figure S6. ${ }^{13} \mathrm{C}$ spectrum $(75 \mathrm{MHz})$ recorded at $\mathrm{rt}$ in $\mathrm{CDCl}_{3}$, of tetra-cationic cryptand $\mathbf{1 . 4 \mathbf { H } ^ { + }}$. 


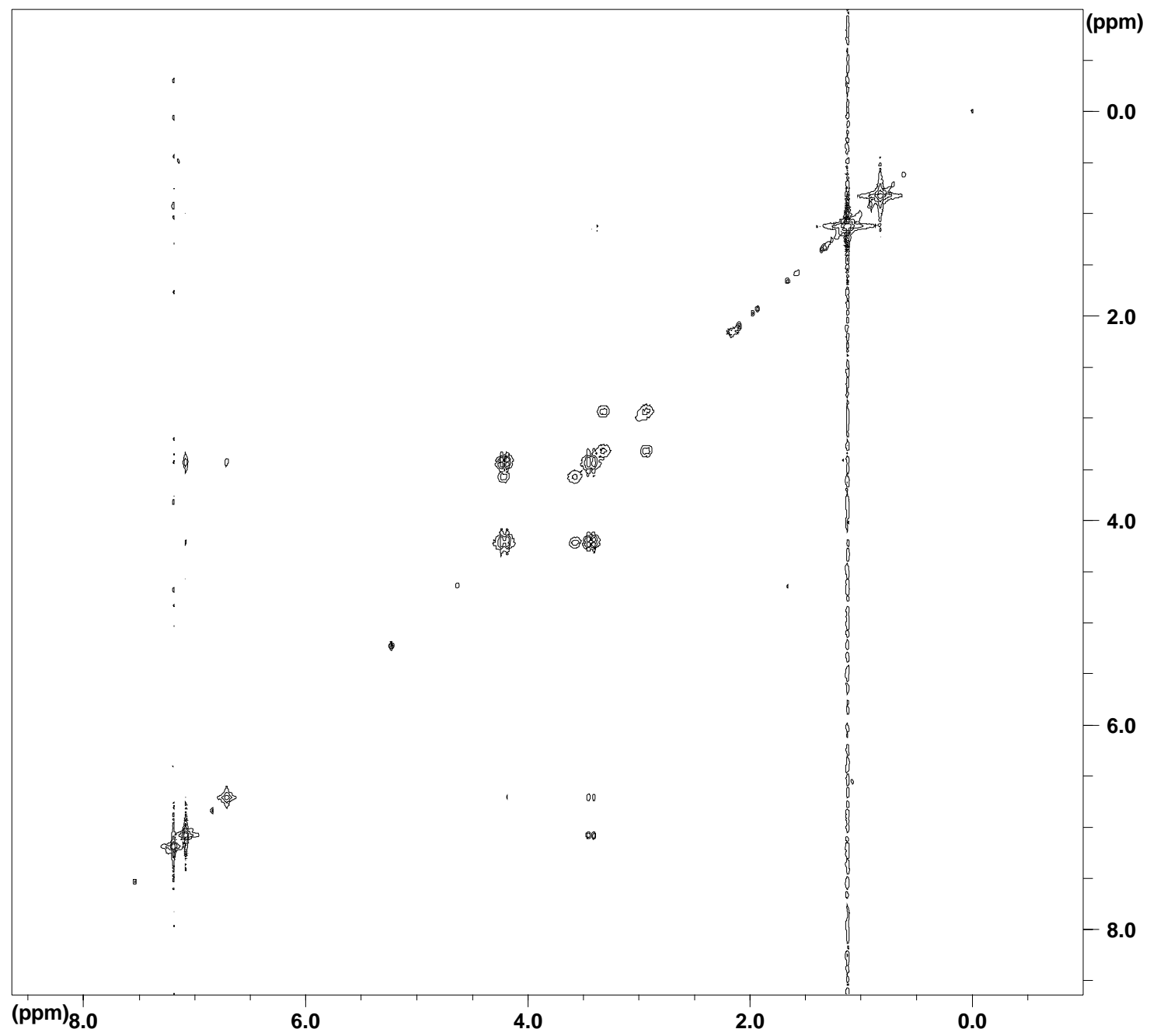

Figure S7. COSY spectrum, recorded at $\mathrm{rt}$ in $\mathrm{CDCl}_{3}$, of tetra-cationic cryptand $\mathbf{1 . 4} \mathbf{H}^{+}$. 


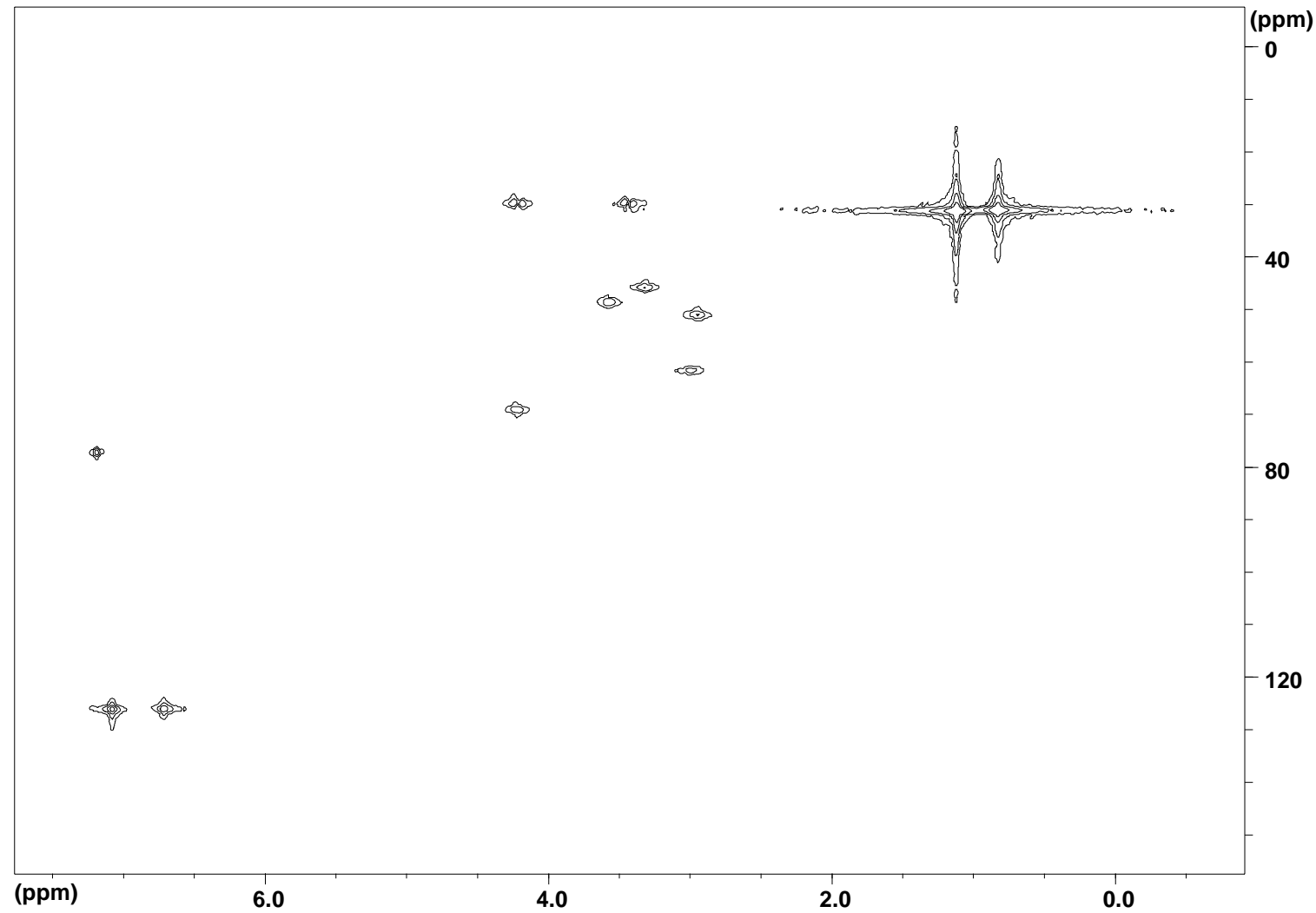

Figure S8. HMQC spectrum, recorded at $\mathrm{rt}$ in $\mathrm{CDCl}_{3}$, of tetra-cationic cryptand $\mathbf{1 . 4 \mathbf { H } ^ { + }}$. 


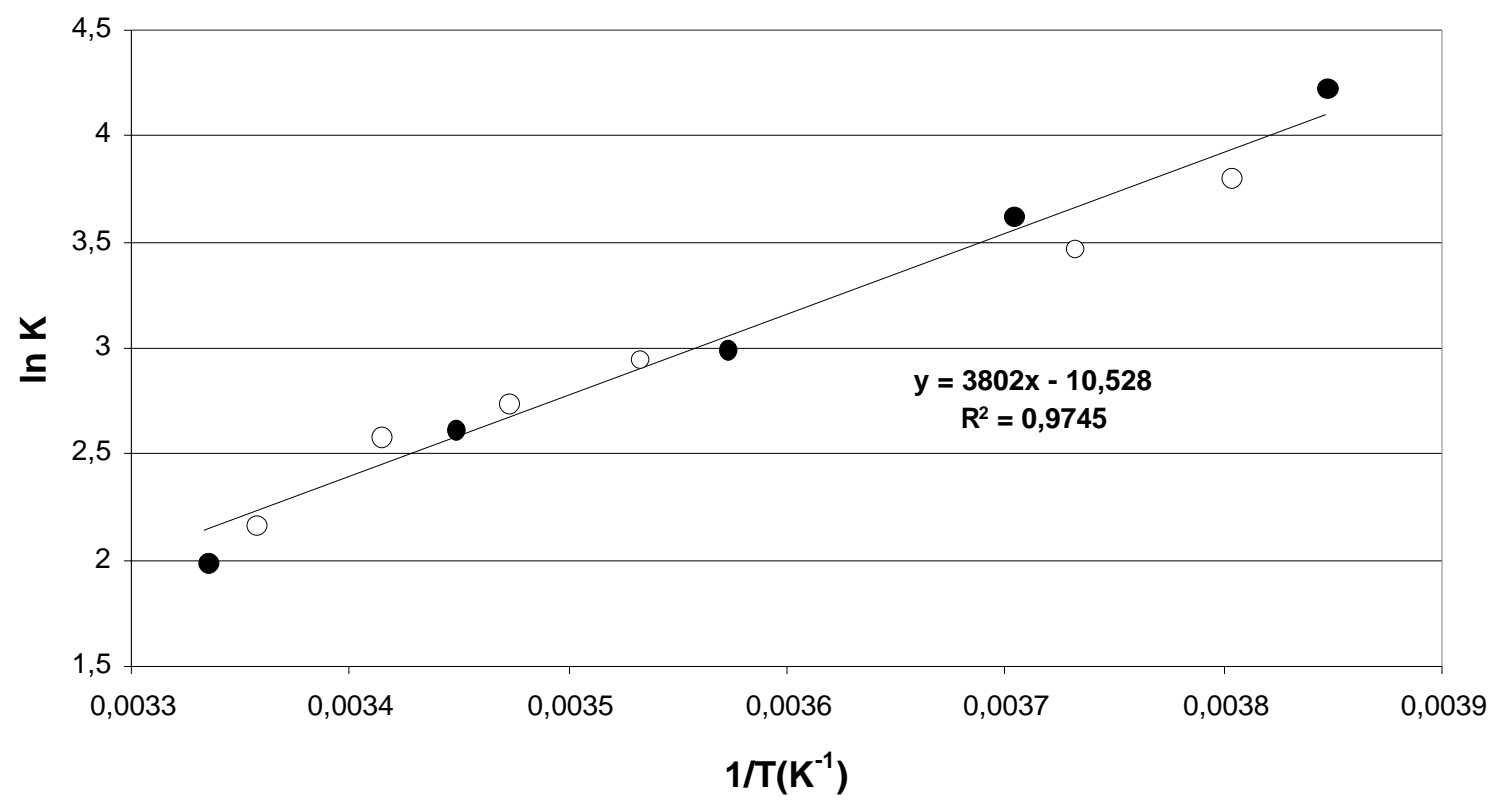

Figure S9. Van't Hoff plot of the equilibrium constant $\mathrm{K}_{\mathrm{DMF} / \mathrm{H} 2 \mathrm{O}}$ determined by ${ }^{1} \mathrm{H} \mathrm{NMR}$ in $\mathrm{CDCl}_{3}$ solution. $[$ complex $]=3.9 \mathrm{mM},\left[\mathrm{H}_{2} \mathrm{O}\right]=200 \mathrm{mM}$, • $[\mathrm{DMF}]=7 \mathrm{mM}$; ०: $[\mathrm{DMF}]=33 \mathrm{mM}$. 